\title{
A METHOD OF PARAMETRIC EVALUATION OF THE TECHNICAL OBJECT RELIABILITY
}

\section{METODA PARAMETRYCZNEJ OCENY STANU NIEZAWODNOŚCI OBIEKTÓW TECHNICZNYCH}

Henryk Borowczyk, Paweł Lindstedt, Jerzy Manerowski

Air Force Institute of Technology, Warsaw; Poland, e-mail: borowczyk@post.p1

\begin{abstract}
This work presents a practical and effective method to evaluate the reliability status of an object basing on the observation of changes in its functioning (automatics) and its technical condition (diagnostics). It has been observed that changes of the functioning condition potential could serve to determine the symptoms of transient (momentary) damages and the changes in the potential of the technical condition to determine the symptoms of parametric damages (non-total). Such an information, as it turns out, is sufficient to calculate reliability characteristics before dangerous catastrophic damages occur and to calculate reliability characteristics for every single object without having to deal with a numerous set of objects. The presented computer-aided method can be of a substantial practical importance in coordination of adjusting/control functions, diagnostics and reliability actions and thanks to that it can improve the level of organisation of a system operation.
\end{abstract}

Keywords: reliability, diagnostic

Streszczenie: W artykule przedstawiono praktyczną i skuteczną metodę oceny stanu niezawodności obiektu, bazującą na obserwacji zmian jego stanu działania (automatyka) i stanu technicznego (diagnostyka). Dostrzeżono, że zmiany potencjału stanu działania mogą być podstawą do wyznaczania symptomów uszkodzeń przemijających (chwilowych), a zmiany potencjału stanu technicznego do wyznaczania symptomów uszkodzeń parametrycznych (niecałkowitych). Tak uzyskana informacja jest wystarczająca do obliczania charakterystyk niezawodnościowych $\mathrm{w}$ czasie przed pojawieniem się niebezpiecznych uszkodzeń katastroficznych oraz obliczania charakterystyki niezawodności dla każdego pojedynczego obiektu bez konieczności dysponowania licznym zbiorem obiektów.

Slowa kluczowe: niezawodność, diagnostyka 


\section{Introduction}

In organised operation systems of complex technical objects one observes their continuous and inevitable degradation. The useful operation achieved with these objects under continuous power and material supply to them decreases. The object failure rate grows, what under limit conditions leads to the object destruction and substantial material losses. Such an undesirable situation causes a continuous natural and growing indeterminacy (disorganisation) of a system (functional randomness of objects) or in other words to a status, where the system redundancy is small (for a fully chaotic system the redundancy equals zero) $[1,8,20]$.

Therefore one strives to find and first of all to perfect proper methods to cope with and counteract these harmful phenomena. It turns out that a good way to solve that problem is to continuously supply an operating system with the negentropy (causes the redundancy to grow) in form of a scientifictechnical information [8].

It is known that as we enter into a system information on the object regulation status, which is determined according to the principles of automatics, and further information on the technical condition of an object determined to the rules of diagnosing as well as an information on the object reliability status, determined according to the reliability theory, we can increase the system redundancy and thus raise its usefulness, decrease its failure rate and also increase the safety.

\section{Cybernetic organised system of operating technical objects}

A simplified scheme of a cybernetic organised system of an operating set of technical objects (airplanes, engines) is shown in Fig. 1.

An operated object (Fig. 1) is supplied with material (operating, safety and protective etc. elements/equipment) and with power (fuel, electric power, hydraulic energy, pneumatic energy etc.). As a result one obtains useful work and an unwanted destruction (putting out of adjustment, part wear, damages). The operating system checks if a system was put out of adjustment (adjustment subsystem), checks on the technical condition of a system (diagnosing subsystem), and identifies and locates damages (damage identification and locating subsystem). 


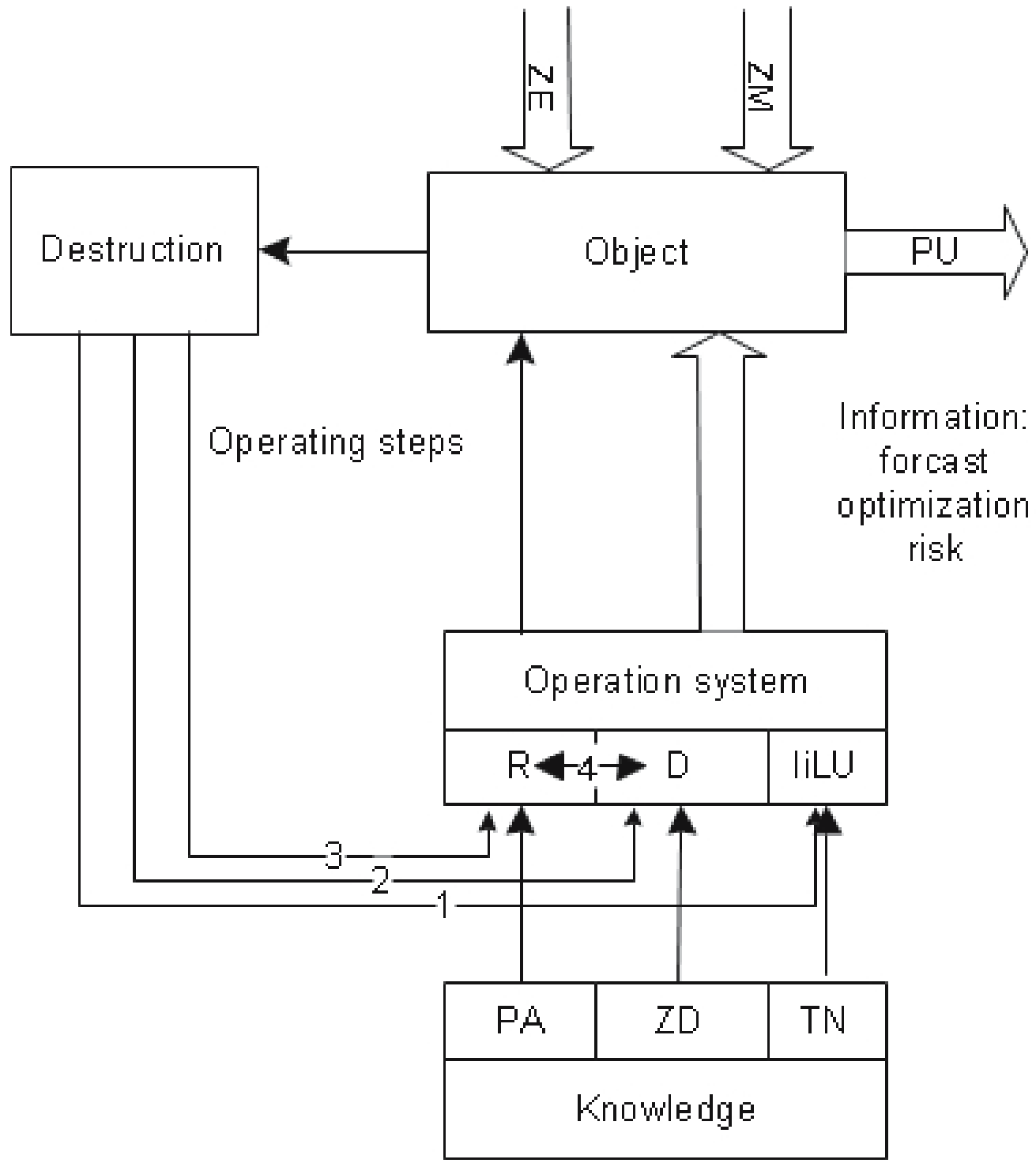

Fig.1 Flow diagram of a cybernetic organised operating system

ZE - power/energy supply, ZM - material supply, PU - useful work, R - adjusting/control, $\mathrm{D}$ - diagnosing, IiLU - damage identification and localisation, PA - automatics principles, ZD - diagnostics principles, TN - theory or reliability, 1,2,3,4 - information paths

The operating system is also supplied with the theoretical knowledge of automatics principles, diagnostic rules and the theory of reliability. Due to that only optimal operation steps are carried out in order to adjust the system, to secure it against excessive wear of components and to protect its 
parts against damages (especially failures which might lead to a catastrophe).

The system of operating the object is systematically fed with information on current changes and forecasts of the adjusting, technical and reliability potential of an operated object, on real limitations of the optimal use whilst not exceeding an allowable risk, and as well with reliability characteristics information $[4,10,11]$.

The information to optimise the system operating actions and its conditions of use results in limiting the object wear and tear, prevents occurrence of critical damages and reduces operating costs and the risk of losing an object.

\section{Principles of reliability calculation}

Broad study of reasons for occurrence of different accidental damages plays an important role in the reliability study $[2,3,16,18]$. By PN, IEC, and GOST standards a damage is a measurable random event, which changes a feature of the object technical condition, i.e. an object change from the state of worthiness into the one of inability, where also by PN, IEC, GOST the state of worthiness is understood as the ability of an object to properly perform a determined work within a determined time.

An occurrence of a damage, i.e. a transition from a state of worthiness into a state of inability, causes the object state of reliability to change, where that change is described quantitatively by reliability factors. In the process of determination of the technical object reliability one takes into account different kinds of damage: a catastrophic (a total damage or destruction), a parametric one (ageing, non-total) and transient (momentary) one - Fig. 1 $[17,18]$. 

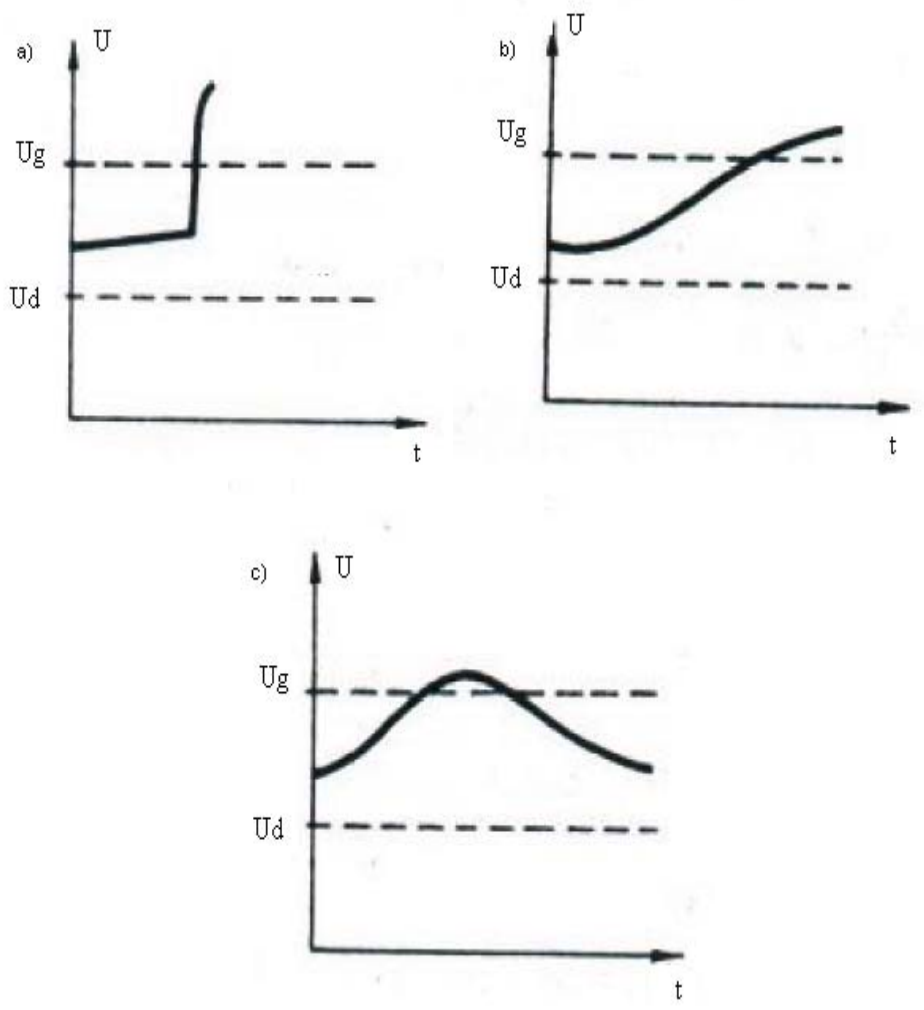

Fig. 2. The process of changes in measurable limits of characteristic features of a technical object $U$ during the time $t$ of its operation:

a) catastrophic, b) parametrical (non-total), c) momentary (transient), $U_{g}, U_{d}$ - lower and upper limit of a characteristic feature of the technical condition.

These damages can be of a different form and the mechanism of their occurrence can be also different, therefore for reliability studies on an operated object the identification of the said damages is of a fundamental significance. The goal of a performed identification is to qualify all the random events, which change an essential feature of the technical condition, into one of the above mentioned damage category (catastrophic, parametrical, or momentary). Therefore there is a need to precisely define individual cases of damages/ failures.

Catastrophic failures (complete) are sudden events leading to a catastrophe i.e. a full disability of a technical object. An object, where a catastrophic failure occurred, will be destroyed and in less critical cases it must be put out of use or be repaired, i.e. broken part must be replaced with new one. In the process of use of different technical objects only a few catastrophic 
failures occur: a break of turbine blade, breaking twist of a shaft connecting a turbine with a compressor, turbine blade partial melting, break of combustion chamber injector, a bearing destruction, break of a strength element, destruction of a fire-resistant coating, tyre rupture etc. These damages are clear and obvious therefore easy to identify. For calculation of reliability factors they absolutely have to be taken into account $[2,18]$.

A parametric defect (non-complete, due to ageing, or degradation) is an event resulting in a gradual incapability of an object. A lot of terms serving to describe these kinds of damages clearly define their character. Therefore it is a damage which at a given moment of operation does not cause an object to be disabled. This is only a premise for a state of disability in the future. One uses to say that an object is in a threatened state, which can be remedied by servicing/repairing it. In the process of use a substantial set of parametric damages occur: small breaks, indentions, a vane break, pitting, erosion losses (which can be removed via e.g. grinding or polishing), and an increased friction in bearings (which e.g. can be remedied by changing oil), and a loss of pressure in a hydraulic or a fuel supply system (which can be remedied by changing the system settings). Identification of parametric damages is difficult. Standard and special measuring systems for inspection (evaluation of the system functioning) and for diagnosing checks (estimation of the system technical condition) are required [2, 18]. For calculations of reliability factors damages of this kind must be taken into account.

A transient (momentary) damage is an event occurring randomly and after some time going back without leaving any clear signs of its occurrence before. It is a damage, which at a given time, does not cause an object to lose its worthiness. During the process of operation transient damages often occur: a momentary excess of the temperature behind an engine turbine, a momentary excessive oil temperature in the lubrication and cooling system, unstable fuel pressure, a fuel supply interruption, unstable run of an engine compressor, a momentary misgoverning of the max rotating speed, a structural overload, a momentary vibration excessive level, etc. (which do not require any service steps or call only for some minor changes of "system" settings). Transient damages are very difficult to identify; checks and diagnostic steps are required. Also such damages (if possible) shall be used to calculate the object reliability factors.

For calculation of reliability factors of a machine, device, or a system its capability probability factor $\mathrm{R}(\mathrm{t})$ must be determined. These calculations must differentiate between three basic kinds of failures: a catastrophic failure, a parametric one and a transient defect. For the analysis of the 
reliability one makes an assumption that different damages occurring are independent events $[2,18]$ and in that case:

$$
R(t)=f\left(R_{a}(t), R_{b}(t), R_{c}(t)\right)
$$

where:

$R_{a}(t)$ - probability of correct functioning of a system affected by a catastrophic failure;

$R_{b}(t)$ - probability of correct functioning of a system affected by a parametric damage;

$R_{c}(t)$ - probability of correct functioning of a system affected by a transient damage;

According to the dependence (1) in order to determine the analytic form of reliability curves $R(t)$ lack of damages estimators must be determined; i.e. estimators of: catastrophic failures $R_{a}^{*}\left(t_{i}\right)$, parametric damages $R_{b}^{*}\left(t_{i}\right)$, and transient damages $R_{c}^{*}\left(t_{i}\right)$, and next the estimator $R^{*}\left(t_{i}\right)$, which takes into account all kinds of discussed damages, failures ( $t_{i}$ time of a damage occurrence).

$$
R^{*}\left(t_{i}\right)=f\left(R_{a}^{*}\left(t_{i}\right), R_{b}^{*}\left(t_{i}\right), R_{c}^{*}\left(t_{i}\right)\right)
$$

The lack of occurrence of catastrophic failures estimator $R_{a}^{*}\left(t_{i}\right)$ is given by a formula:

$$
R_{a}^{*}\left(t_{i}\right)=\frac{n_{a}-m_{a}(t)}{n_{a}}
$$

where:

$m_{a}\left(t_{i}\right)$ - the number of catastrophic failures within the $\left[0, t_{i}\right]$ period;

$n_{a}$ - the number of all the catastrophic failures within the expected lifetime of objects from the set under discussion;

The lack of parametric damage occurrence estimator $R_{b}^{*}\left(t_{i}\right)$ is given by the following formula:

$$
R_{b}^{*}\left(t_{i}\right)=\frac{n_{b}-m_{b}(t)}{n_{b}}
$$

where:

$m_{b}\left(t_{i}\right)$ - the number of parametric damages within a $\left[0, t_{i}\right]$ time period;

$n_{b}$ - the number of all the parametric damages (which can be removed) within an expected lifetime of an object; 
The $R_{c}^{*}\left(t_{i}\right)$ - i.e. lack of transient damage occurrence estimator is given by the following formula:

$$
R_{c}^{*}\left(t_{i}\right)=\frac{n_{c}-m_{c}(t)}{n_{c}}
$$

where:

$m_{c}(t)$ - the number of transient damages within a $\left[0, t_{i}\right]$ time period;

$n_{c}$ - the number of all the momentary (transient) damages within an expected lifetime of an object;

Practically the reliability curve $R(t)$ is calculated basing only on a small number of $R_{a}^{*}\left(t_{i}\right)$ estimators (for this kind of damages one assumes that $\left.R_{b}^{*}\left(t_{i}\right)=1, R_{c}^{*}\left(t_{i}\right)=1\right)$ :

$$
R^{*}\left(t_{i}\right)=R_{a}^{*}\left(t_{i}\right)
$$

More and more often apart from the $R_{a}^{*}\left(t_{i}\right)$ estimator also $R_{b}^{*}\left(t_{i}\right)$ estimators are taken into account. Therefore for that case we determine the $R_{a}^{*}\left(t_{i}\right)$ from experiments with a set of objects, $R_{b}^{*}\left(t_{i}\right)$ - analytically, assuming that $R_{c}^{*}\left(t_{i}\right)=1 \quad[18,19]$.

$$
R^{*}\left(t_{i}\right)=R_{a}^{*}\left(t_{i}\right) R_{b}^{*}\left(t_{i}\right)
$$

A new method to determine reliability curves is to determine the $R(t)$ only with estimators of less dangerous damages $R_{b}^{*}\left(t_{i}\right)$ and $R_{c}^{*}\left(t_{i}\right)[10,11,12]$.

Symptoms of these damages are obtained from a universal description of an object, which bases on the two intercorrelated equations of state $[5,11]$ :

$$
\begin{aligned}
& \frac{d u}{d t}=a_{R_{c}} u+b_{R_{c}} D \\
& \frac{d D}{d t}=a_{R_{b}} D+b_{R_{b}} u
\end{aligned}
$$

where:

$u$ - vector of control signals resulting from the operation of a technical object:

$D$ - the vector of diagnostic signals related to the technical condition of an object;

$a_{R_{c}}$ - the parameter of the state of control (operation);

$b_{R_{c}}$ - the parameter of the impact of a technical state on the possibility of control;

$a_{R_{b}}$ - the parameter of the technical condition (diagnosis);

$b_{R_{b}}$ - the parameter of the impact of the quality of control on the changes of the technical condition. 
Changes of parameters $\mathrm{a}_{\mathrm{Rc}}$ and $\mathrm{a}_{\mathrm{Rb}}$ resulting from the sequence of $U$ and $D$ signals for known observed operation periods of these signals are calculated with (8) and (9) formulas.

Changes of $a_{R_{b}}$ and/or $a_{R_{c}}$ parameters in excess of the $\sigma$ standard deviation are regarded as signs of parametric damages $m_{b}$ and/or transient damages $m_{c}$. Reliability estimators $R_{b}^{*}\left(t_{i}\right)$ and $R^{*} c\left(t_{i}\right)$ are calculated with relationships (4) and (5), and next with the formula (7) the $R^{*}\left(t_{i}\right)$ is determined $[10,11,12]$.

\section{Identification of the reliability characteristics}

For the identification of the $R(t)$ reliability characteristics (as an analytical function) on the basis of $R_{b}^{*}\left(t_{i}\right)$ and $R_{c}^{*}\left(t_{i}\right)$ estimators the best approximating function is determined. According to PN, IEC and GOST standards it can be a normal exponential or Weibull distribution function.

To solve this problem one applies the method of the smallest sum square of approximation errors. In this method the $S$ functional represented by the (10) equation should be equal to the minimum value $S_{\min }[13,14,15]$.

$$
S=\sum_{i=1}^{n}\left[R^{*}\left(t_{i}\right)-R\left(t_{i}\right)\right]^{2}
$$

$n$-the number of calculated estimators

The $R(t)$ function is assumed arbitrary (e.g. a Weibull distribution) and its parameters (e.g. $a, b$ ) are determined by equalling functional (10) partial derivatives to zero in relation to searched parameters:

$$
\frac{\partial S}{\partial a}=0 \quad ; \frac{\partial S}{\partial b}=0
$$

From all the recommended forms of the reliability function $R(t)$ for a practical attendance of machines the Weibull function is a very important one:

$$
R(t)=e^{-\left(\frac{t}{a}\right)^{b}}
$$

where:

$a$ - the parameter of damage intensity rate (the number of damages per 1000 hours of operation);

$b$ - the form parameter (where it can be $b<1, b=1, b>1, b=2, b>2$ ) 
The Weibull distribution $[6,17,18]$ was derived basing on experimental experience. Its properties are universal.

- with $b=1 a(t)=$ const, and the Weibull distribution takes on the form of a exponential distribution.

- with $b>1 \quad a(t)$ increases according to a root function.

- with $b=2$ the Weibull distribution takes the form of a Rayleigh distribution and $a(t)$ grows

- with $b<1 \quad a(t)$ decreases non-linearly.

For all cases with $b>1$ and $a(t)$ growing, the form of the Weibull distribution approaches the normal distribution.

Where $b<1$ and with $a(t)$ falling - the Weibull distribution form approaches the gamma distribution.

Therefore a conclusion ensues that the combination of the Weibull distribution function can be used to describe a typical and very often occurring practically damage rate intensity function in the form of Ufunction, called a "tub" function - (machine running-in: $a(t)$ decreases, normal wear - $a(t)$ is constant and with an intensified wear $a(t)$ is growing) $[6,16,18]$.

In addition the Weibull distribution is widely used for estimation of the reliability of mechanical parts and electro-mechanical parts and as well of electronic components.

The estimation or identification (by a direct use of the formula (12)) of parameters $a$ and $b$ by the method of smallest squares - formulas (10) and (11) - is not simple, therefore seldom used in the process of operating an object. For this reason there is a need to work out a method of a quick and effective procedure to identify parameters $a$ and $b$ of an assumed Weibull distribution.

\section{New method of identification of reliability characteristics parameters in the form of the Weibull function}

The suggested method is based on the Weibull function described by the (12) formula

$$
R(t)=e^{-\left(\frac{t}{a}\right)^{b}}=e^{-\lambda t^{b}} ; \quad \lambda=\left(\frac{1}{a}\right)^{b}
$$

Having found the logarithm of (13) we obtain:

$$
\ln R(t)=\ln e^{-\lambda t^{b}}
$$


and next:

$$
r(t)=-\lambda t^{b}
$$

where:

$$
r(t)=\ln R(t)
$$

In the discussed case the functional of the optimisation of the smallest sum square method will take the following form:

$$
S_{L}=\sum_{i=1}^{n}\left(r_{i}^{*}+\lambda t_{i}^{b}\right)^{2}=\sum_{i=1}^{n}\left(r_{i}^{* 2}+2 r_{i}^{*} \lambda t_{i}^{b}+\lambda^{2} t_{i}^{2 b}\right)
$$

where:

$$
r_{i}^{*}=\ln R^{*}\left(t_{i}\right)
$$

The $\lambda$ and $b$ parameters are determined from:

$$
\begin{gathered}
\frac{\partial S_{L}}{\partial b}=\sum_{i=1}^{n}\left(2 \lambda t_{i}^{2 b} \ln t_{i}+2 r_{i}^{*} t_{i}^{b} \ln t_{i}\right)=0 \\
\frac{\partial S_{L}}{\partial \lambda}=\sum_{i=1}^{n}\left(2 \lambda t_{i}^{2 b}+2 r_{i}^{*} t_{i}^{b}\right)=0
\end{gathered}
$$

Therefore:

$$
\begin{aligned}
& \sum_{i=1}^{n}\left(\lambda t_{i}^{2 b} \ln t_{i}+r_{i}^{*} t_{i}^{b} \ln t_{i}\right)=0 \\
& \sum_{i=1}^{n}\left(2 \lambda t_{i}^{2 b}+2 r_{i}^{*} t_{i}^{b}\right)=0
\end{aligned}
$$

If we assume the $b$ parameter value is known, then with the relationship (19) we can calculate the $\lambda$ parameter value:

$$
\lambda=\frac{\sum_{i=1}^{n} r_{i}^{*} t_{i}^{b}}{\sum_{i=1}^{n} t_{i}^{2 b}}
$$

The essence of the suggested algorithm of determination of analytical reliability characteristics parameters in the form of the Weibull function is to search the null point of the $F$ function resulting from the (18) relationship

$$
F=\sum_{i=1}^{n}\left(\lambda t_{i}^{2 b} \ln t_{i}+r_{i}^{*} t_{i}^{b} \ln t_{i}\right)
$$

at an equality limiting condition (20) brought to a form of (21).

To calculate $\lambda$ and $b$ parameters we assume first that $b=1$. Further we proceed as follows: 
Step 1: For a given value of the $b$ parameter determine the $\lambda$ parameter value from (21).

Step 2: Determine the value of the $F$ function from (22).

Step 3: If the absolute value of the F function exceeds a permissible error $\varepsilon$ take a new value of the $b$ parameter and return to Step 1 . New values of the parameter $b$ are assumed so as to with next iterations the absolute value of the function $F$ went down.

Step 4: Determine the value of parameter $\lambda$,

$$
a=e^{\alpha} ; \alpha=\frac{1}{b} \ln \frac{1}{\lambda}
$$

Step 5: Write down the determined parameters of the Weibull distribution.

The selection of $b=1$ results from experience gained from reliability tests with technical objects - the time of operation, when the damaging intensity rate a is constant, $a=$ const, is the longest, so it is most sure and most easy to identify.

According to an up-to date experience of operating systems one assumes that with $b=1$ an object is at a stage of normal use, with $b<1$ it is being runin and with $b>1$ its wear is increased, $b=2$ its wear is intensified (the intensity rises in a linear way) and finally with $b>2$ an object is subject to a failure wear (the intensity grows in a non-linear way).

Further information on the state of reliability results from changes in the $a$ value. Low $a$ value and low $\Delta a$ increments evidence a correct reliability status of an object.

\section{Verification if the method is practically effective}

Table 1 below lists data on damages of different objects gained from experience.

The table lists time points when damage occurred (catastrophic failure, parametric damage and transient damage) for selected technical objects. Basing on formulas (3), (4) and (5) we determine $R_{a}^{*}\left(t_{i}\right), R_{b}^{*}\left(t_{i}\right), R_{c}^{*}\left(t_{i}\right)$ for given time, and next $R^{*}$ and $\ln R^{*}$. 
Table 1

\begin{tabular}{|c|c|c|c|c|c|c|c|c|c|c|c|c|}
\hline \multirow[b]{2}{*}{ Obiekt } & \multirow[b]{2}{*}{$\begin{array}{l}\text { Failu } \\
\text { re }\end{array}$} & \multicolumn{10}{|c|}{ Events } & \multirow{2}{*}{$\begin{array}{c}\text { Number } \\
\text { of } \\
\text { possible } \\
\text { faults }\end{array}$} \\
\hline & & $\mathrm{z}_{0}$ & $\mathrm{z}_{1}$ & $z_{2}$ & $z_{3}$ & $z_{4}$ & $z_{5}$ & $\mathrm{z}_{6}$ & $z_{7}$ & $z_{8}$ & $\mathrm{z}_{9}$ & \\
\hline \multirow{3}{*}{$\begin{array}{l}\text { Allison 250 } \\
\text { engine [4] }\end{array}$} & $\mathrm{m}_{\mathrm{a}}$ & $0 / 0$ & & & $1 / 800$ & & & & & & & \multirow{3}{*}{160} \\
\hline & $\mathrm{m}_{\mathrm{b}}$ & $0 / 0$ & $1 / 200$ & & & & $1 / 1100$ & & & & & \\
\hline & $\mathrm{m}_{\mathrm{c}}$ & $0 / 0$ & & $1 / 400$ & & $1 / 1000$ & & & & & & \\
\hline \multirow{3}{*}{$\begin{array}{c}\text { Pump group } \\
{[11]}\end{array}$} & $\mathrm{m}_{\mathrm{a}}$ & $0 / 0$ & & & & & & & & & & \multirow{3}{*}{300} \\
\hline & $\mathrm{m}_{\mathrm{b}}$ & $0 / 0$ & & $1 / 8720$ & & & $1 / 8950$ & & & & & \\
\hline & $\mathrm{m}_{\mathrm{c}}$ & $0 / 0$ & $1 / 8350$ & & $1 / 8760$ & $1 / 8830$ & & $1 / 9322$ & 1/15182 & $1 / 15312$ & $1 / 15388$ & \\
\hline \multirow{3}{*}{$\begin{array}{l}\text { Anthropotech } \\
\text { nical system } \\
\text { heli-copter- } \\
\text { pilot [12] }\end{array}$} & $\mathrm{m}_{\mathrm{a}}$ & $0 / 0$ & & & & & & & & & & \multirow{3}{*}{105} \\
\hline & $\mathrm{m}_{\mathrm{b}}$ & $0 / 0$ & $1 / 1150$ & & & & $1 / 1650$ & $1 / 1670$ & & & & \\
\hline & $\mathrm{m}_{\mathrm{c}}$ & $0 / 0$ & & $1 / 1250$ & $1 / 1315$ & $1 / 1645$ & & & & & & \\
\hline \multirow{3}{*}{$\begin{array}{l}\text { Weibull } \\
\text { distribu-tion } \\
\text { parameters } \\
\text { [17] }\end{array}$} & $\mathrm{m}_{\mathrm{a}}$ & $0 / 0$ & $13 / 35$ & $107 / 40$ & $80 / 45$ & $50 / 50$ & $50 / 70$ & $310 / 120$ & & & & \multirow{3}{*}{1100} \\
\hline & $\mathrm{m}_{\mathrm{b}}$ & $0 / 0$ & & & & & & & & & & \\
\hline & $\mathrm{m}_{\mathrm{c}}$ & $0 / 0$ & & & & & & & & & & \\
\hline
\end{tabular}

We have to keep in mind that $n_{a}$ from the formula (3) is the number of all the objects and $n_{b}$ and $n_{c}$ are the numbers of all possible occurrences of parametric and transient damage events within the expected lifetime of an object, as determined from the following relationship:

$$
n_{b}=\frac{T_{r e s} m_{b}}{T_{o b s}} ; n_{c}=\frac{T_{r e s} m_{c}}{T_{o b s}}
$$

where:

$T_{\text {res }}$ - expected lifetime (service life);

$T_{\text {obs }}$ - observation time in service life units;

$m_{b}$ - the number of possible parametric damages within an observation time $T_{\text {obs }}$;

$m_{c}$ - the number of possible transient damages within an observation time $T_{\text {obs }}$;

On the basis of the [14] programme, which realises the above-presented algorithm the Weibull distribution parameters were determined - Table 2.

The correct functioning of the programme was verified by comparing results obtained from the programme, which executes the suggested algorithm, to results obtained from an evaluation of the Weibull distribution parameters of a standard Excel programme (the concordance is sufficient and the precision and the result accuracy according to the new method is significantly greater). 
Table 2. Weibull distribution parameters

\begin{tabular}{|l|l|r|r|}
\hline \multicolumn{1}{|c|}{ Object } & \multicolumn{1}{|c|}{ Event series } & \multicolumn{1}{c|}{$\mathrm{a}$} & \multicolumn{1}{c|}{$\mathrm{b}$} \\
\hline Allison 250 engine [4] & $\mathrm{z}_{0}, \mathrm{z}_{1}, \mathrm{z}_{2}, \mathrm{z}_{3}$ & 235,3700 & 0,7236 \\
\cline { 2 - 4 } & $\mathrm{z}_{0}, \mathrm{z}_{1}, \mathrm{z}_{2}, \mathrm{z}_{3}, \mathrm{z}_{4}, \mathrm{z}_{5}$ & 40,4292 & 0,9549 \\
\hline Pump group [11] & $\mathrm{z}_{0}, \mathrm{z}_{1}, \mathrm{z}_{2}, \mathrm{z}_{3}, \mathrm{z}_{4}, \mathrm{z}_{5}$ & 1,1652 & 26,5893 \\
\cline { 2 - 4 } & $\mathrm{z}_{0}, \mathrm{z}_{1}, \mathrm{z}_{2}, \mathrm{z}_{3}, \mathrm{z}_{4}, \mathrm{z}_{5}, \mathrm{z}_{6}$, & 10,1945 & 1,5463 \\
& $\mathrm{z}_{7}, \mathrm{z}_{8}, \mathrm{z}_{9}$ & & \\
\hline $\begin{array}{l}\text { Anthropotechnical system } \\
\text { helicopter - pilot [12] }\end{array}$ & $\mathrm{z}_{0}, \mathrm{z}_{1}, \mathrm{z}_{2}, \mathrm{z}_{3}$ & 1,5381 & 8,2205 \\
\cline { 2 - 4 } & $\mathrm{z}_{0}, \mathrm{z}_{1}, \mathrm{z}_{2}, \mathrm{z}_{3}, \mathrm{z}_{4}, \mathrm{z}_{5}, \mathrm{z}_{6}$ & 2,4210 & 3,3666 \\
\hline $\begin{array}{l}\text { Weibull distribution } \\
\text { parameters [17] }\end{array}$ & $\mathrm{z}_{0}, \mathrm{z}_{1}, \mathrm{z}_{2}, \mathrm{z}_{3}, \mathrm{z}_{4}, \mathrm{z}_{5}, \mathrm{z}_{6}$ & 1,1348 & 1,6268 \\
\hline
\end{tabular}

To sum it up, one can state that in the process of an object operation changes in $a$ and $b$ shall be recorded and next basing on them it is possible to evaluate the changes in the reliability status of every examined technical object.

\section{Conclusions}

The knowledge of the object functioning, on its technical and its reliability status, is of a fundamental importance to ensure proper operation of such an object. It has been found that the observation of changes in the operational status and in the technical condition can serve as a basis to determine signs of parametric and transient damages and, consequently on that basis, to calculate the parameters of the Weibull reliability characteristics for each particular object.

The above-described way of calculating the reliability is characteristic of its possible execution before any catastrophic failures occur and moreover without having to analyse a set of objects.

\section{Bibliography}

1. Ashby R. W., Wstęp do cybernetyki, PWN, Warszawa 1963

2. Bobrowski D., Modele i metody matematyczne w teorii niezawodności, WNT Warszawa 1985

3. Borowczyk H., Lindstedt P., Manerowski J.:Premises for a Practical Computer-Aided parametric Method of Evaluation of the Technical Object Reliability. Journal of KONES, Vol. 16 No 2, Warsaw 2009

4. Borowczyk H., Lindstedt P., Przesłanki sterowania procesem eksploatacji układu łożyskowania silnika turbinowego na podstawie kompleksowej informacji diagnostycznej. Diagnostyka 1(45) 2008

5. Cempel C. Teoria i inżynieria systemów. WITE Radom 2006 
6. Fidelis E., Firkowicz S., Grzesiak K., Kołodziejski J., Wiśniewski K. Matematyczne podstawy oceny niezawodności. PWN, Warszawa 1966

7. Jaźwiński J., Żurek J.: Wybrane problemy sterowania zapasami. WITE Radom 2007

8. Lerner A. J.: Zarys cybernetyki. WNT Warszawa 1971

9. Lewitowicz J., Kustroń K.: Podstawy eksploatacji statków powietrznych, T. 2. Wyd. ITWL Warszawa 2003

10. Lindstedt P.: The method of complex Worthiness Assessment of an Engineering Object in the process of its Use and Service. Solid State Phenomena, Vol. 141 (2009), pp. 45-52, Trans. Tech. Publications, Switzerland

11. Lindstedt P., Sudakowski T.: Method of Prediction of Reliability characteristics of Pumping Station on the base of Diagnostic Information. Journal of KONBiN, Vol. 11 No 2(5) 2008 pp. 202-222, Warsaw

12. Lindstedt P., Sudakowski T.: Possibilities of Assessment of Reliability of an Antropotechnical System. Journal of Vibroengineering, Vol 9, Issue 4, 2007, Vilnius

13. Manerowski J.: Identyfikacja modeli dynamiki ruchu sterowanych obiektów latających. Wyd. Naukowe ASKON, Warszawa 1999

14. Manerowski J.: jerzy.manerowski@itwl.pl

15. Oprzędkiewicz J., Stolarski B.: Komputerowe monitorowanie niezawodności samochodów. PWN, Warszawa 2000

16. Poradnik Inżynieria niezawodności pod redakcją Migdalskiego J. ATR Bydgoszcz, ZETOM Warszawa 1992

17. $\mathrm{PN}-87 / \mathrm{N}-04030$

18. Sotskow B. S.: Niezawodność elementów i urządzeń automatyki. WNT Warszawa 1973

19. Tomaszek H., Żurek J., Jasztal. H.: Prognozowanie uszkodzeń zagrażających bezpieczeństwu lotów statków powietrznych. Wyd. Nauk. ITE-PIB Warszawa 2008

20. Wiener N.: Cybernetyka czyli sterowanie i komunikacja w zwierzęciu i maszynie. PWN Warszawa 1971 
PhD. Eng. BOROWCZYK Henryk, Air Force Institute of Technology, Bialystok University of Technology, specialization: complex diagnostics of turbine engines and control systems, system identification, methods of artificial intelligence.

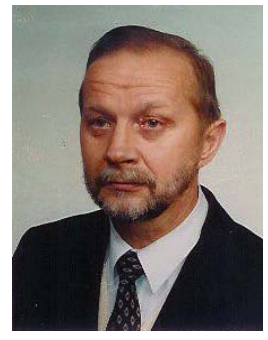

Prof. Pawel Lindstedt - professor of the Air Force Institute of Technology. Research subjects: Construction and utilisation of machines, applied automatics, diagnostics and reliability of machines. His works concern diagnostics of aircraft engines, hydraulic systems, and bearing systems with functional, vibro-acoustic and wear methods.

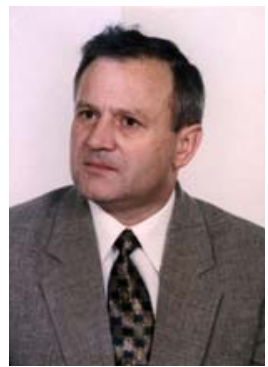

Prof. Jerzy Manerowski - professor of the Air Force Institute of Technology. Research subjects: Modeling and control of arial vehicles. Identyfication of air vehicles characteristics. Modeling of flight dynamics using artificial naural networks. 